\title{
Britain's Housing Disaster and Its Effects on Young People
}

No issue has come to define the Millennial generation, and their blasted hopes, more than housing. For previous generations, going back until the 1970s when the late baby boomers came of age, housing proved to be a major source of wealth accumulation and 'lifestyle mobility', if not for all, then at least for a majority. If social mobility were measured in intergenerational changes in consumer power, then housing asset accumulation would have been counted a major engine of mobility both for baby boomers, and for the X Generation (born 1965-1979) that followed them. For the Millennial generation, by contrast, the protracted housing crisis has proven to be the major barrier to their life chances, and the main symbol of intergenerational declines in opportunity. Whereas young people in the previous generation had an odds on chance of owning a house by the age of $30,{ }^{1}$ and if not, of renting decent homes at affordable at prices, for today's young people in many parts of the country, the chances of either are becoming increasingly remote.

The underlying causes of the UK's 'housing disaster'2 are complex and they involve each of the drivers of changing youth opportunities discussed at the outset. Demographics have played their part, since ageing populations increase the demand for housing space, because of the high percentage of older people living alone, many of whom prefer not to downsize their accommodation when one partners dies. Other demographic trends are also contributing to increasing demand. Rising divorce rates and other changes in patterns of family formation and lifestyle choice, have meant than more people live in single-person households 
than before (up to 14 percent of the over 16s in 2014). ${ }^{3}$ Between 1970 and 2005 the population in Britain increased by eight percent while the number of households increased by 30 percent. ${ }^{4}$ Population growth and the declining size of household units increase the demand for homes.

At the same time fewer new houses are being built. Governments and private developers have both been responsible. An average of 308,000 new homes were completed each year between 1951 and 1984, roughly half of them by local councils. At the peak in 1968, 425,000 new homes were completed. But from the early 1980s councils virtually stopped building and private developers failed to fill the gap. Between 1998 and 2009 on average only 191,000 were completed each year. ${ }^{5}$ Home building reached a new low in 2012, with less than 100,000 completed, only 31 percent of which for social housing. Local councils built just 2.7 percent of new homes, around 3000, across the UK. ${ }^{6}$ Building has recovered has only slightly subsequently, with 139,030 new homes completed in the year to June $2016 .^{7}$

Governments since the 1980s have been increasingly reluctant for the state to be the main supplier of housing and have followed their neoliberal instincts in hoping that the private market would fill the gap. Councils have been obliged to sell existing council homes under Right to Buy and have been prevented from replacing them through caps on their borrowing. After 2007 austerity has made government even more reluctant to finance the building of new homes. On the other hand, developers have often been more interested in building luxury and higher-priced homes than affordable homes that yield a lower profit. What is more, given the historic tendency for the price of land and houses to rise rapidly, developers will often leave their land under-developed, hoping that prices will go higher, thus increasing their profits when they do build. In July 2016 there were 684,000 unfinished building sites with detailed planning permission and building work had not even started on half of them. ${ }^{8}$

However, shortage of supply has not necessarily been the only, or even the main, problem. There is more housing space available now per head of population than at any time in history. In 1931 there were an average of 4.2 people for each dwelling. Now there are 2.3. Research by Rebecca Tunstall shows that the average number of rooms available for each person has increased substantially over the years, from one in 1921 , to 1.5 in 1971 and 2.4 in $2011 .^{9}$ According to the 2011 census for England and Wales the average household comprised 5.4 rooms and 
2.7 bedrooms, with 2.4 rooms per person and 1.2 bedrooms per person. Oxford University social geographer Danny Dorling estimates there were in total 66 million bedrooms in England and Wales for 55 million people, and that given the number of couples sharing a bed, there would have been a 'surplus' of bedrooms of about 22 million. ${ }^{10} \mathrm{He}$ also calculates that there are currently enough empty properties to house two million people. The Office for National Statistics (ONS) calculated that there were roughly 27.5 million dwellings (excluding long-term vacant houses) and 26.5 million households in $2013 .{ }^{11}$

The problem is not so much that we lack housing stock, but that much of it is in the wrong place and the wrong people are buying it, including foreign investor buyers and buy-to-let landlords. Housing generally has become much more unequally distributed. As the Danny Dorling writes: 'The great housing insecurity of our times has been brought about by a minority becoming hoarders of property, and this hoarding has been encouraged by successive governments. ${ }^{12}$

Rebecca Tunstall's research shows that housing inequality declined in the middle decades of the 20th century, along with income and wealth inequality generally. In 1921 the richest tenth of households had four times as many rooms per person as poorest tenth, but by 1981 they had three times more. ${ }^{13}$ However, the distribution of housing become more unequal again after 1980, along with incomes and wealth. The ratio of rooms per person between the top and bottom deciles increased from $3: 1$ in 1981 to $3.7: 1$ in 2001 and to $5: 1$ in $2011 .{ }^{14}$ Growing inequality in access to housing space was not only made possible by increasing income and wealth inequality generally, which allowed richer people to buy very large houses, way in excess of their needs, and for quite a substantial proportion of adults to own second homes ( 17 percent in the UK at the last count). It was also encouraged by policies amongst successive governments which promoted the idea that housing was a profitable market for speculation, as much as a means to fulfill human needs for shelter, privacy and comfort.

There have been tax privileges for home ownership going back many decades. Until it was cut back in the 1980s and finally abolished in 2000 , individual home ownership was strongly encouraged by the provision of tax relief on mortgage interest (MIRAS in its last incarnation). However, what has happened since then is that tax privileges have been directed towards those buying multiple homes to rent for profit. Buy-tolet landlords have received special tax and mortgage terms which have 
greatly increased the profitability of renting out properties as a business, so that the returns to investing in properties for rent now greatly exceed the normal return on the stock market. A 2014 report by Paragon, one of Britain's leading buy-to-let lenders, found that since 1996 investment in buy-to-let properties had averaged an annual rate of return of 16 percent, far outstripping the return on shares and bonds at 6.8 and 6.5 percent respectively. ${ }^{15}$ Even without rents, returns to housing investment have outpaced the average returns to FTSE100 companies over the past 20 years by 7.3 percent compared with 6.3 percent. ${ }^{16}$ In fact the increase in the value of property generally has so far exceeded that of the stock market, that Martin Weale estimates that property is now 50 percent over valued compared with stocks. ${ }^{17}$

In addition, housing remains one of the few capital assets that is not subject to capital gains tax (CGT). It is true that second homes are nominally subject to CGT on sale, but the rules are so easily evaded by multiple home owners switching houses temporally - to classify second as first homes before selling - that the provision is more honoured in the breach than the observance. In conjunction with the de-regulation of the private rental market since the 1980s, which makes the exploitation of tenants by landlords much easier, all this has greatly encouraged the notion that investing in residential property is for profit rather than for personal needs. The financialisation of the mortgage lending market since the mid 1980s, with the de-mutualisation of building societies, and the globalisation and de-regulation of banking generally, has also under-written the process of transforming residential property from a matter of home ownership to financial speculation. ${ }^{18}$ A new class of landlords has grown on the back of this. According to Savills, landlords with mortgages now have more housing market equity than owner-occupiers with mortgages. ${ }^{19}$

The result of all this has been a seemingly inexorable rise in house prices. Between 1983 and 2007, just before the bubble burst, nominal house prices had risen by a multiple of six, many times faster than wages. ${ }^{20}$ For young people buying in the years between 1970 and 1990 , first-time buyer home prices had been, on average, at an affordable 2.4 times their average incomes. For those buying between 1997 and 2009 the ratio had risen to a quite unaffordable 3.41 to $1 .{ }^{21}$ By 2016 the average home was costing almost eight times average earnings and twice that ratio in London. ${ }^{22}$ At their peak in 2007, just before the crash, mortgages for first time buyers were at 3.4 times their average income (suggesting purchasing prices, which generally exceed loans, at almost 4:1). 
By 2010 the average deposit was at $£ 56,000$, roughly double the average wage. ${ }^{23}$ Those who could get mortgages, not surprisingly, tended to borrow at very high loan to value ratios (median advances were at 90 percent LTV), and many had to resort to 'interest-only' deals to make their mortgage payments affordable ( 24 percent of all loans), thus diminishing their home ownership status to a more secure form of renting. ${ }^{24}$

The effect of all this has been to put home ownership increasingly out of reach for most young people. Not surprisingly, fewer and fewer are buying houses. In 1990, 50 percent of home owners were under 35 year old age. Just 20 years later this fraction had dropped to 29 percent. ${ }^{25}$ In 1985,34 percent of under $25 \mathrm{~s}$ were already home-owners. This dropped to 19 percent by 2005 . Among $25-29$ year olds, owner occupation rates were down from 62 percent at their peak in 1985 to 46 percent 20 years later. By 2007 the mean age of first time buyers had risen to 32 and 37 for those without parental assistance. ${ }^{26}$ Owner occupation amongst the under 30s was already a minority experience by 2007 but it was likely to become even rarer in the years to come. According to the projections produced by the Joseph Rowntree Foundation, the total number of 18-30 year olds owning their own homes is likely to drop from 2.4 million in 2008 to 1.3 million by 2020 . Whereas around 35 percent of $18-30$ s owned their homes in 1997, only about 25 percent did so in 2008 . By 2020 that proportion is predicted to drop to around 12 percent. ${ }^{27}$

If buying has become near impossible for most young people, other alternatives, whether they be social housing or private renting, are equally problematic. Social housing has been declining remorselessly for three decades. In 1980 local councils provided accommodation for 31 percent of the country's households. After the 1980 Housing Act, much of this stock was sold off (at 40-60 percent below market value) under the Right to Buy initiative. With much reduced central government funding for council house building in the ensuing years, councils replaced very few of the 1.85 million council houses sold off, ${ }^{28}$ so that by 2008 council tenants made up only 16 percent of households. ${ }^{29}$ Housing Association provision failed to take up the slack. The result has been ever lengthening waiting lists for council housing. Young people are least likely to qualify for these occupancies, unless they have dependent children, because they have not had time to advance themselves up the queue, so not many of them get access to this dwindling stock of affordable housing. Whilst 14 percent of 18-30 year olds were in some form of social housing in 1997, only nine percent were so in $2015 .{ }^{30}$ 
The remaining alternative for young people leaving home has been privately rented accommodation in a sector which had grown rapidly, not least as a result of financial crisis and subsequent restraints on home loans. ${ }^{31}$ The proportion of young people renting in the private sector has thus increased substantially, from around 12 percent in 1997, to 28 percent in 2015 , and it is projected to rise to 33 percent by $2020 .{ }^{32} \mathrm{In}$ many countries with better regulated private rental markets this might not be such a bad thing. But the problem for young people forced to rent privately in the UK it that the sector is less regulated than in almost any other country in Europe. ${ }^{33}$ Consequently, tenures are insecure, housing quality is often poor, and prices are often excessively high.

According to the National Housing Federation the cost of renting rose a massive 37 percent in the five years to 2012, and it has been going up at a rapid rate since then. ${ }^{34}$ In London in 2012 rents rose eight times faster than incomes. By 2012 , average monthly rents had reached $£ 744$ nationally and $£ 1102$ in London. They have continued to rise in London and other cities in southern in England at an astronomical rate. Recent hotspots have been southern university towns like Brighton and Bristol, where rents rose by an average 18 percent in 2015 alone. ${ }^{35}$ Many young people are having to spend so much on rent that saving for a deposit an impossibility. Data for 2014/2015 from the English Household Survey show average private tenants paying over half of their household incomes on rent. ${ }^{36}$ For young people with lower earnings the proportion would be even higher.

But the high costs of renting are not the only problem. Despite the sky-high rents, the quality of properties is often very poor, with many properties reported as not safe for human habitation. Amongst those interviewed by the British Household Panel Survey in the early 2000s, those in privately rented accommodation were more than twice as likely as owner occupiers to report problems with condensation, lack of adequate heating and damp. ${ }^{37}$ Buy-to-let landlords typically have small property portfolios which they maintain alongside other jobs. They are thus part-time and essentially amateurs in the role of renting accommodation, typically knowing less about landlord/tenant law and tenants' rights than traditional landlords. ${ }^{38}$ Unfortunately, a proportion of them fail to keep their properties in good repair and at a standard fit for tenants and evidence is emerging that this is increasingly common. The Migrants' Rights Network claims that Ealing may have as many as 60,000 occupants in illegal structures, and Slough, reportedly, has up to 6000 'beds in sheds'. Recently we have seen the rise of 'rent-to-rent' 
which in some cities is becoming synonymous with multi-occupancy in poor quality dwellings. ${ }^{39}$

According to a recent investigation by Shelter, official complaints against landlords to local authorities rose by 27 percent in the three years to 2012 , with a total of 85,000 complaints in the last of those years. ${ }^{40}$ Of those complaints, 62 percent were about serious and life-threatening hazards. Tenants most frequently complain of landlords refusing to make necessary repairs. However, when tenants do complain they can find themselves subject to 'revenge evictions' by landlords who presume they can always find another tenant, who will probably pay an even higher rent. The number of evictions by a private landlord has risen by 60 percent over five years from 2010/2011 to 37,000 annually. Over the same period, as the 2016 'Monitoring Poverty and Social Exclusion' report points out, mortgage repossessions have fallen to from 23,000 to $3300 .{ }^{41}$

Not the least amongst the problems faced by renters in the private sector is the extreme level of insecurity they face. Since the de-regulation of the privately rented sector in the 1980s, landlords have been free to evict tenants after a year, in practice for any reason they wish. John Major's 1996 Housing Act introduced the Assured Shorthold Tenancy, allowing tenants and landlord to give notice after just six months. As a result private landlords, spurred on by their agents, have come to believe that they should raise their rents annually and tenants, unable able afford another rent hike, frequently end up moving within the year. The length of tenure amongst those who have the freedom to choose is typically about seven years. The median stay in a dwelling for owner-occupiers is 7.1 years and that for social renters 7.8. In contrast, the median private tenant stays only 1.7 years before moving on. ${ }^{42}$ The increasing precariousness of tenures amongst private renters has been associated with higher levels of 'risk' and uncertainty and with associated threats to wellbeing and health. ${ }^{43}$ Indeed, the most commonly cited source of the relationship between housing tenure and ill-health in the academic literature is 'ontological insecurity' - the feeling of being unsafe in their world. ${ }^{44}$

For many young people, who still dream of owning their own homes, this is a no-win situation. More and more decide to stay living in the family home, so that they can at least save towards a mortgage deposit. Others, the so-called 'boomerang children,' end up returning to live with their parents after failed attempts at independent living in the private rental jungle. By 2011,29 percent of males aged 20-34s and 18 percent of women were still living in the parental home. ${ }^{45}$ Those who do prolong 
residence in the family home are more likely to have parents who own houses, and have the space to accommodate them, or alternatively, to have insufficient income to rent privately. Surveys report that they are also more likely to say they are delaying entering long-term relationships and starting families because they can't get their own accommodation.

The current housing crisis, which shows no signs of abating, represents the biggest single barrier to young people getting on with their lives and taking the traditional steps towards adult status. At one level it is a vivid example of the delaying of transitions for young people, and many young people perceive it this way and still hope to be owning homes before too long. A MORI poll in 2016 found that 80 percent of 25-34 year olds would like to be owner occupiers in five years time, if they had the choice, a similar proportion to all adults. ${ }^{46}$ However, for many their hopes are unlikely to be fulfilled. Today's young people will carry the burdens of the dysfunctional housing market bequeathed by previous generations with them throughout their lives. The majority may never own their own homes at all, if current trends in declining home ownership continue.

Those that do manage to get on the ladder, will take longer to pay off their mortgages and thus be saddled with higher debts into late middle age, just when they need to be saving for their retirement on meagre pensions. The lucky ones will have inherited from their parents or been gifted funds to buy homes when they were younger. But this is a minority of all young people, with just 27 percent of first-time buyers getting help from family and friends in raising the deposit for a mortgage. ${ }^{47}$ Older people are increasingly having to down-size their homes to release equity to pay for health care or to fund their longer retirements. By the end of the 2000s, 30-50,000 properties were being sold each year to pay for care, while 160,000 houses were left in estates annually. ${ }^{48}$ Only one in six parents were leaving a house to their children, which suggests that no more than one third of the children's generation were benefiting, and then in most cases not until their middle age. When the current generation of young people reach middle age their parents homes will be even more valuable than they are now, but less of that value will be passed on because more of the parents will have 'spent the inheritance. ${ }^{49}$

Britain's disastrous housing system is undoubtedly at the heart problem of intergenerational inequalities. The baby boomers and, to a lesser extent, the Xers who followed them, were hugely fortunate as generations. They bought houses when they were relatively cheap, many of them council houses at highly discounted rates; the older ones saw their 
mortgage burdens ease rapidly in the inflationary 1970s; and they ending up owning valuable properties which they could use as collateral for more borrowing and spending in middle age. Many of them could sit back and watch their property wealth rise inexorably, increasing by more each year than they were earning from work. Indeed in the South East of England in 2015 house prices were still rising annually by an average $£ 29,000$ - by almost $£ 5000$ more than average pay. ${ }^{50}$

The scale of this money making machine was surreal. The value of the 18 million or so homes in the UK rose on average by about $£ 100,000$ in the seven years preceding the financial crisis. ${ }^{51}$ If 15 million of their owners were owner-occupiers throughout the decade their collective housing assets would have grown by about $£ 1.5$ trillion. That sum was roughly equivalent to our annual GDP and considerably more than the UK public debt. Even netting out for inflation and home improvement costs you can estimate private gains of over one trillion pounds in that decade alone. ${ }^{52}$ These gains were not going to young people, since in 2008 the under $35 \mathrm{~s}$ owned just 3.2 percent of Britain's $£ 2.9$ tn of housing stock. ${ }^{53}$ These property gains therefore represents a transfer of wealth from the future generation of home-buyers to the existing 35 plus generation of home owners in the order of magnitude of the 2008 UK GDP in just seven years.

The intergenerational imbalances do not stop there. The inflated rents paid by young people today are mostly going to older adults. About two million adults now act as landlords. ${ }^{53}$ Many of these are buy-to-let investors, who took 13 percent of all mortgages granted in 2012. Of these investors, 58 percent were aged 46-65. On the other hand, over half of all private renters are estimated to be under 35 years. ${ }^{54}$ If Britain is fast returning to an age of rentier capitalism, last seen in the Edwardian era, as Thomas Piketty maintains, it is the older generations who form the core of this new class of landlords. And they have been aided and abetted by governments which under-regulate the private rental market; spend in excess of $£ 27$ bn on housing benefits, much of it going to private landlords, and until 2016, gave special tax privileges to buy-to-let landlords.

With over-heated housing markets, and returns on investment way above the stock market average, the incentives for this new breed of amateur landlords are huge. But unfortunately for younger people they are hiking house prices further, at the same time as reducing the quality and security of rented accommodation, since it is the amateur landlords who are least likely to maintain properties. They are also more likely to want to give notice to tenants because when you own just a couple of 
properties you are more likely to want to take back your small rented property at short notice, either because a member of your family suddenly needs housing, or for your own use, because finances have got a bit tight, or to perform the temporary address switch that people with second homes regularly make to avoid paying capital gains tax on the sale of a second home.

\section{Intergenerational Decline Meets Social Class Polarisation}

Of all the domains in which young people see their opportunities restricted, housing represents the most serious, and the one which most clearly represents a growing gap between generations in life time opportunities. As they grow older most young people may well catch up with their parents' generation in terms of jobs and earnings. Yet in housing, we are witnessing a genuine divergence in intergenerational fortunes, which will almost certainly affect the majority of the young generation throughout their lifetimes. However, at the same time this generational decline is cross-cut by growing class divisions amongst young people. Housing opportunities are becoming increasingly polarised by social class and social background. In England, where homeownership has been a major vehicle for social mobility for two post-war generations, class polarisation in housing opportunities now works to reduce it.

Analysis of the trends in housing tenure during the medium term show quite clearly that we are experiencing both a substantial social class polarisation in access to the most desirable forms of housing, as well as an overall intergenerational decline. Our own analysis of the trends between 1991 and 2013, using the data from the British Household Panel Survey and its successor Understanding Society, shows not only how far the patterns of tenure amongst young people have changed in recent decades, but also how this has affected young people in all occupational groups. It also shows a stark polarisation in tenure patterns by social group and social background.

Between 1991 and 2013 the proportion of young people aged 18-34 in England owning their own homes almost halved, declining from 46 to 25 percent (See Fig. 4.1). The proportion who were social renters also declined, from 15 to 12 percent. At the same time the proportion living with parent(s) rose from 29 to 42 percent, and proportion renting privately increased from ten to 21 percent. Most of the decline in home ownership 


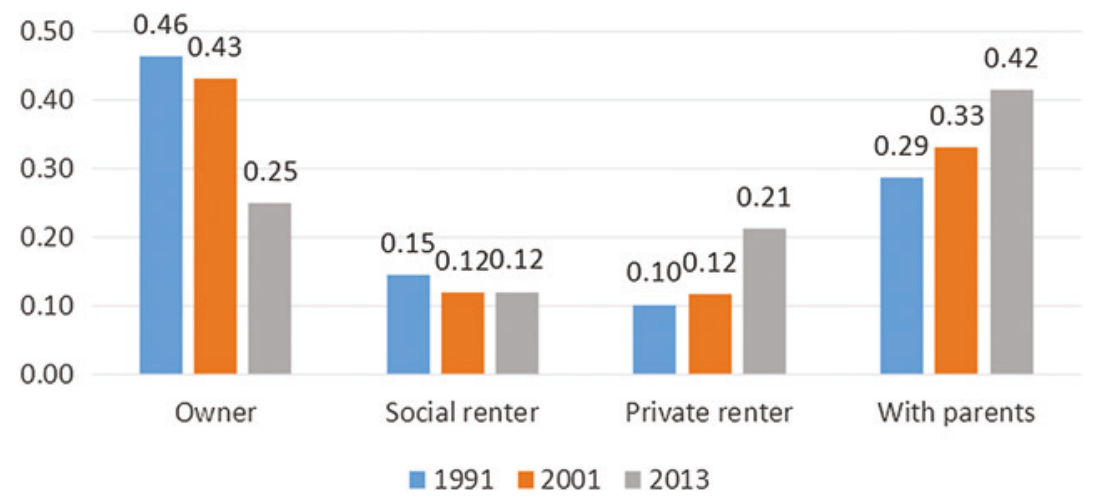

Fig. 4.1 Trends in proportion of 18-34 year olds in England in different tenures, 1991, 2001, 2013. Source Calculations from British Household Panel Survey/UK Household Longitudinal Study data: Weighted estimates

happened after 2001, with those who would formerly have bought homes now staying in the parental home or renting privately.

The decline in home ownership amongst young people affected all socio-economic groups. Taking 18 to $34 \mathrm{~s}$-reflecting the fact that the most now cannot buy home until their 30s-Fig. 4.2 shows that all groups have experienced declines between 1991 and 2013, mostly occurring in the 2000s. The proportion of young people in professional and associate professional jobs who owned their home dropped by 26 percentage points over this 22 year period, with only half being owners by the end. For those employed in non-graduate jobs the declines were even greater: around 38 percentage points for those employed in skilled (manual or non manual) jobs and 39 percentage points for those in semi- and unskilled jobs. Less than a quarter in the latter category owned their own homes by 2013. The declines in home ownership for those in skilled and semi- and unskilled jobs appear to have started earlier than for those in professional jobs, being apparent already by 2001 when professional home ownership still maintained its 1991 level. However, the decline in home ownership for young professionals was particularly sharp during the house price boom years after 2001 and by 2013 all groups of young people had substantially less chance of owning a home than 22 years previously.

However, whilst this is a generational issue, with all social groups amongst todays' young people less likely to be owners than the earlier 


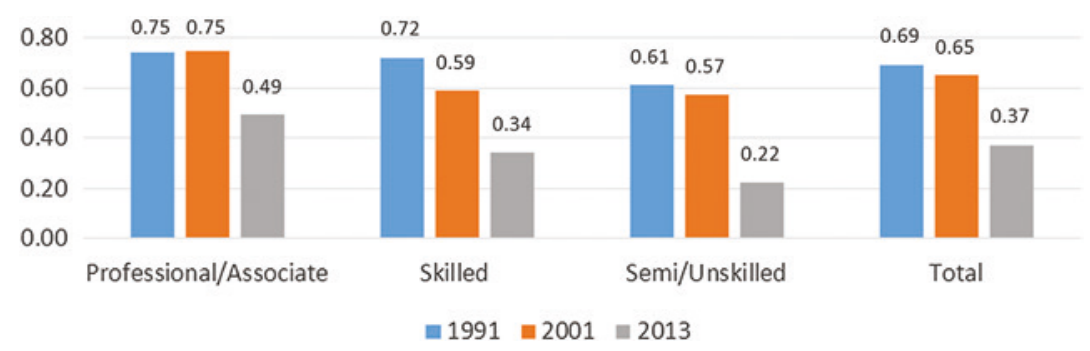

Fig. 4.2 Trends in proportion of home owners by occupational class for 25-34 year olds, 1991, 2001 and 2013. Source Calculations from British Household Panel Survey/UK Household Longitudinal Study data: Weighted estimates

generation at the same age, it is also a manifestation of growing inequality. Figure 4.3 shows for different years the odds ratios for owning a house of professionals and associate professionals, and those in skilled jobs, compared with those in semi- and unskilled jobs. In 1991, compared with young people in semi- and unskilled jobs, professionals were 1.85 times as likely to own a home and those in skilled jobs were 1.65 times as likely. By 2013 the odds ratios had increased substantially so that, compared with young people in semi- and unskilled jobs, those in professional jobs were now 3.35 times as likely to own a home and those in skilled jobs 1.78 times as likely. Inequality in home ownership increased across the whole class social spectrum but particularly at the top end.

During the same period, the effect of social background on the chances of young people in England owning a home also increased substantially. Figure 4.4 shows the trends in the odds ratios for owning a home of young people with parents in different occupational groups (when the children were 14 years old). In 1991, compared with young people with parents in semi- and unskilled jobs, those with parents in professional and associate professional jobs were 1.44 times as likely to own a home, and those with parents in skilled jobs were 1.34 times as likely. By 2013, those with parents in skilled jobs were now 1.55 times as likely to own a home as those with parents in semi- and unskilled jobs. The increase over time in the odds ratio was even larger for those from more privileged backgrounds. By 2013, young people whose parents had professional jobs were now 2.39 times as likely to own a home as those whose parents had semi- or unskilled jobs. The estimates for 2001 are not significant, but since the changing patterns of home ownership 


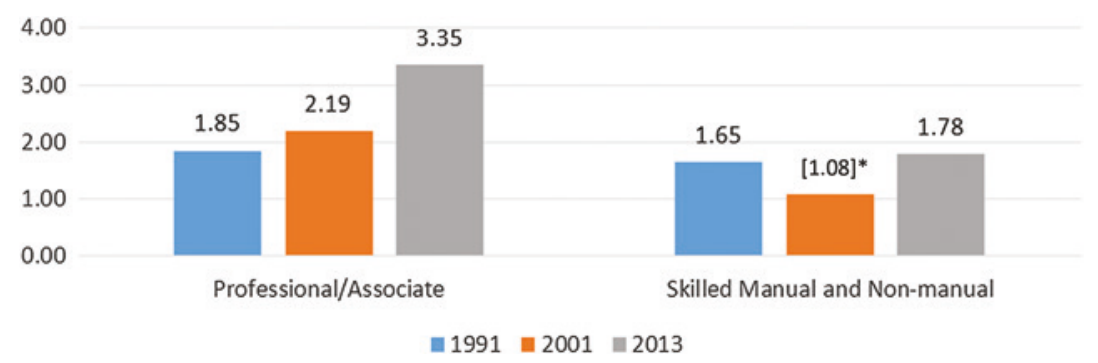

Fig. 4.3 Trends in odds ratios for owning accommodation amongst 25-34s by occupational class. Source Calculations from British Household Panel Survey/ UK Household Longitudinal Study data: Weighted estimates. The odds ratios are computed cross-sectionally on the three waves of BHPS-UKHLS : 1991, 2001 and 2013. Note ${ }^{*}$ Means that the estimated odds ratio is not significant at the 95 percent confidence level

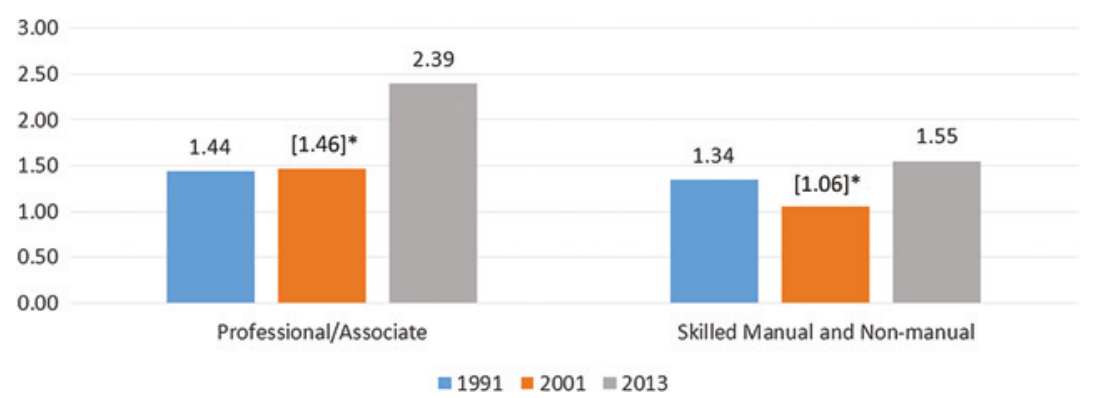

Fig. 4.4 Trends in odds ratios for owning a home amongst 24-34s in England by parental occupational class. Source Calculations from British Household Panel Survey/UK Household Longitudinal Study data: Weighted estimates. The odds ratios are computed cross-sectionally on three waves of the BHPS-UKHLS survey, for years 1991, 2001 and 2013. Note ${ }^{*}$ Means that the estimated odds ratio is not significant at the 95 percent confidence level

occurred mostly in the 2000s we may assume that these changes in home social background effects on home ownership happened mostly in that period as well.

During a two-decade period when the relative benefits of home owning, compared with renting, have never been bigger, both in terms of quality of tenure and wealth accumulation, we have seen inequalities 
in housing opportunities almost double between children of professional and semi- and unskilled families. The possibility to own a home is increasingly limited to the third or so of young people from better-off families who inherit or get substantial help with their mortgage deposits. For the rest the chances of home ownership are very low.

As housing mobility has declined, so the gaps in ownership between young people in different social classes has increased. And this sharp increase in housing tenure inequality which we observe amongst todays' young people is likely to persist as their cohort grows older. Indeed, it may well increase as those on higher incomes who have not yet been able to buy a home by age 34 finally manage to get on the housing ladder in middle age, some with help from parental gifts or inheritances, while a large proportion of those on lower incomes, often without the benefit of parental gifts or inheritances, remain permanently excluded. So the housing opportunities for a whole generation, through its life course, will have become more unequal than for the preceding generation during its lifetime.

But growing housing inequality remains only one part of the story of intergenerational changes in housing opportunities. The other side is that a whole generation, throughout its lifetime, will have a worse experience of housing than their parents' generation had. Each socio-economic group will have had to wait longer on average to own a home and the chances of doing so at any age will have declined. Those who succeed amongst the current generation will have had to pay more to buy a home than their parents did, and the price they pay will have a been financial bonus to their parents' generation, which they will be unlikely to inherit in full since their parents will often have used this to fund retirement and care in older age. Because the current generation who buy homes are having to pay such high prices, they will also be burdened with higher debts than their parents throughout most of their lifetimes, which will limit consumption capacity and lifestyle options even when they achieve incomes at comparable levels to their parents in time. 
Open Access This chapter is licensed under the terms of the Creative Commons Attribution 4.0 International License (http://creativecommons.org/licenses/ by $/ 4.0 /$ ), which permits use, sharing, adaptation, distribution and reproduction in any medium or format, as long as you give appropriate credit to the original author(s) and the source, provide a link to the Creative Commons license and indicate if changes were made.

The images or other third party material in this chapter are included in the chapter's Creative Commons license, unless indicated otherwise in a credit line to the material. If material is not included in the chapter's Creative Commons license and your intended use is not permitted by statutory regulation or exceeds the permitted use, you will need to obtain permission directly from the copyright holder.

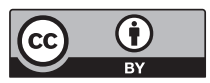

